\title{
The Improvement of Cadres Knowledge Throught Strengthening of Social Capital in Agam District Year 2014
}

\author{
Fauziah Elytha ${ }^{1}$, Rizanda Machmud ${ }^{2}$, Rita Damayanti ${ }^{3}$, Nusyirwan Effendi ${ }^{4}$ \\ ${ }^{1}$ Student of the doctoral program in public health, Andalas University, Padang, Indonesia \\ ${ }^{2}$ Faculty of Medicine, Andalas University, Padang, Indonesia \\ ${ }^{3}$ Faculty of Public Health, University of Indonesia, Jakarta, Indonesia \\ ${ }^{4}$ Faculty of Social and Political Sciences, Andalas University, Padang, Indonesia
}

\begin{abstract}
Agam is one of filariasis endemic areas in the West sumatera, it need mass treatment. TAS survey obtained $7.7 \%$ of elementary school students positively infected filarial after 6 year mass treatment. Data of medication coverage were not fulfill the target of $85 \%$. These results indicate that interventions for health cadres is necesery. Health cadres have role in the distribution and socialization at mass treatment on filariasis prevention. Aims this intervention is increasing public compliance taking a medications. This research use Mix-Methode (quantitative and qualitative) approach with quasi-experimental before-after control design to health cadres and the qualitative research with in-depth interviews to determine the existence of social capital at mass treatment on filariasis prevention. Assessment of medication coverage by cross-sectional. Results show that there was an increasing of cadre's knowledge as much as $26.8 \%$ after refreshing program (p value $=0.001)$. Attitude has increased, but statistically not significant $(p$ value $=0.201)$. Results of in-depth interviews revealed that there was social capital in the socialization and motivation at mass treatment on filariasis prevention. Medication adherence in the intervention area (18.9\%) more increasing then in the control area (13.1\%) p-value of 0.001 in intervention area and 0,093 in control. There was an increasing in knowledge and attitudes after the intervention. The existence of social capital in efforts improvement medication adherence and increasing in medication adherence in the study area. Department of Health at Agam district should take advantage of social capital that was growing up in the community to in efforts increasing the medication coverage..
\end{abstract}

Keywords: Social capital, filariasis, medication adherence.

\section{Introduction}

Lymphatic filariasis disease is one of the oldest parasitic disease in the world ${ }^{[1]}$. The surveys show more than 6 million people in Indonesia infected with filariasis and reported more than 8243 of them suffer from chronic clinical filariasis ${ }^{[2]}$. One of filariasis endemic areas at West Sumatra province is Agam district with the discovery of microfilaria prevalence of $8.5 \%$ in 2004 , mass treatment held at 2005 to $2011^{[3]}$.

Medication adherence at mass treatment on filariasis prevention from 2005 until 2011 not get a target. Effect this problem are incidence of filariasis and results of the Transmission Assessment Survey (TAS) still high, there are indicate the spread of new infections in some regions of Agam District. Poor adherence as a result of the inability to provide cadres directly or through partnerships with community leaders that the medication is safe for consumption.

Green explains that there are three factors that influence individual behavior are the predisposing factors ( knowledge, perceptions, attitudes and beliefs), Enabling factors (partnerships with community health workers in this case, including health cadres) and reinforcing factors (attitudes and behavior of influential people in this training, theory and supervision) ${ }^{[4]}$.
Center for Health Research university of Indonesia examine among 101 respondents who were involved with medication distribution and 400 community members in Agam at 2013. the research found that total of $81 \%$ community received the medication and $71 \%$ consume it. Among 50\% community get The medication that distributed by Cadres, while community leaders were responsible for only $8 \%$. The factor of decision to consume the Lymfatic Filariasis medication is their own self-awareness. In this research also find that cadres is the most widely participated in addition to health personnel, religious leaders and community leaders has participate less. The cadres responsible around $52.4 \%$ distribution of elephantiasis medication and $18.4 \%$ socialization/education, while knowledge the giver and receiver medication still low, only $53.4 \%$ of giver and $22.9 \%$ of recevier know that cause elephantiasis is a filarial worm disease.

Wijaya found that there is a statistically significant relationship between knowledge, attitudes and motivation with the activity of a health Cadres. Cadres with high knowledge have the possibility to be active 18 times greater than the Cadres with lower knowledge, Cadres with good attitude have the possibility to Actively 8 times greater than the Cadres with low attitude ${ }^{[5]}$. Cadres with high motivation have possibility to be active 15 times greater than the health Cadres with low motivation ${ }^{[5]}$. Ambarita found the generaly people in the village of Rimba Terab, Banyuasin District, 


\section{International Journal of Science and Research (IJSR) \\ ISSN (Online): 2319-7064}

Index Copernicus Value (2013): 6.14 | Impact Factor (2014): 5.611

have a low knowledge about filariasis ${ }^{[6]}$. This affects a person's adherence to consume medication at MDA. Improving knowledge of cadres is one of the effective ways to improve public knowledge about filariasis. cadres with high knowledge will participate to be as village health promoters who are working voluntarily, chosen by the community and having responsibility to develop society can be realized ${ }^{[7]}$.

Therefore, it is necessary to intervene in the form of There is necessary intervene refreshing program to the cadres. refreshing program about confidence (trust), cooperation and solidarity and responsibility in order to be able to increase medication adherence at mass treatment on filariasis prevention in Agam District. The purpose of this research is to improve medication coverage of prevention of filariasis in Agam District through refreshing to health cadres by strengthening social capital involved knowledge and attitude.

\section{Method}

This study using two approaches, quantitative and qualitative (mix method). Quantitative research design was used "QuasiExperiments" before and after control design for a cadre of primary research. The design of "Cross Sectional" is used to assess the treatment coverage. Qualitative research is used to find out more related to social capital at MDA. Subjects were health cadres.

The research was conducted in Agam district by selecting one of three sub district (sub district Lubuk Basung, Sub District Tanjung Mutiara and Sub District IV Nagari ), which it is the study sample of center for health reseach of indonesian university. Selection of sub district Lubuk Basung was done purposively because in this district have two health centers and commonly found Clinical filariasis cases.

The quantitative data colected by distributing questionnaires to a cadre of medication. Qualitative research through observation, interview and documentation, using secondary data from Center for Health Research university of Indonesia in 2014, evaluating on filariasis mass treatment coverage in Agam District in 2013. the background of Using data of Center for Health Research university of Indonesian because researcher joint in that program. Data of Center for Health Research university of Indonesia for intervention and control areas was obtained from questionnaires to see medication adherence in the mass treatment.

There are 3 variables in this research, including predisposing factors (knowledge, perceptions, attitudes, and beliefs), enabling factors (partnership health workers) and reinforcing factors (attitudes and behavior). Data collected using questionnaire, interview, observation and documentation. Quantitative data analysis using logistic regression.

Intervention cadres with refreshing about filariasis with the strengthening of social capital will improve the Knowledge, Attitude and Practice of Cadres in socialization MDA. Improving the ability of these cadres will give effect to the increased coverage of taking medication MDA 2014.

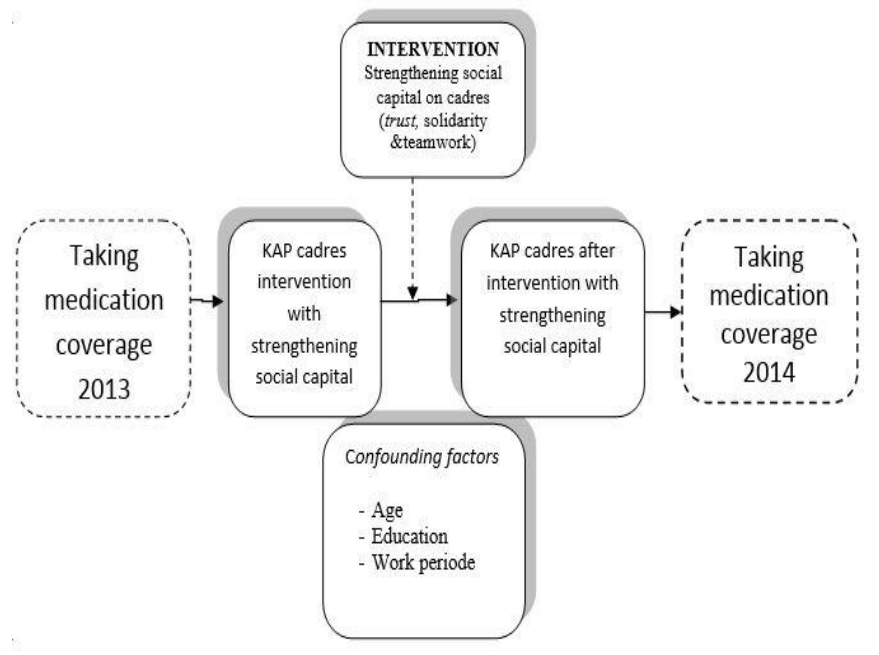

Figure 1. FrameworkConcept of research

\section{Result}

Total cadres in study area are 370 people were 261 cadres at intervention areas and 109 cadres at control area. The characteristics about cadres was analizing by categorizing Age, length of work and level of education, that comparing cadres at the intervention and control areas.

Table 1: Characteristics of cadres

\begin{tabular}{|c|c|c|c|c|c|}
\hline \multirow{2}{*}{ Variable } & \multicolumn{2}{|c|}{ Intervention } & \multicolumn{2}{|c|}{ Control } & \multirow{2}{*}{$p$ value } \\
\hline & $f$ & $\%$ & f & $\%$ & \\
\hline \multicolumn{6}{|l|}{ Age } \\
\hline$<35$ years & 79 & 30,3 & 42 & 38,5 & \multirow[t]{2}{*}{0,155} \\
\hline $\begin{array}{r}\text { Length of Work } \\
\geq 35 \text { years }\end{array}$ & 182 & 69,7 & 67 & 61,5 & \\
\hline$\geq 5$ years & 148 & 56,3 & 77 & 70,6 & \multirow[t]{2}{*}{$0,014^{*}$} \\
\hline$<5$ years & 113 & 43,7 & 32 & 29,4 & \\
\hline \multicolumn{6}{|l|}{ Level of Education } \\
\hline Hight ( $(\mathrm{SMA})$ & 170 & 65,1 & 63 & 57,8 & \multirow[t]{3}{*}{0,225} \\
\hline Low (< SMA) & 91 & 34,9 & 46 & 42,2 & \\
\hline Total & 261 & 100 & 109 & 100 & \\
\hline
\end{tabular}

Age and level education in the two area have same caracteristics, there is is a litle diference. Pencentages cadres with length of work $\geq 5$ year in control area greater then in intervention area.

Table 2: Knowledge of Cadres Before and After Treatment

\begin{tabular}{|c|c|c|c|c|c|c|c|}
\hline \multirow{3}{*}{ PreT est } & \multicolumn{6}{|c|}{ Pre T est } & \multirow{3}{*}{$\begin{array}{c}p- \\
\text { value }\end{array}$} \\
\hline & \multicolumn{2}{|c|}{$>$ median } & \multicolumn{2}{|c|}{$<$ median } & \multicolumn{2}{|c|}{ Total } & \\
\hline & $f$ & $9 \%$ & $f$ & $\%$ & $f$ & $9 \%$ & \\
\hline$\geq$ mean & 119 & 45,59 & 11 & 4,22 & 131 & 50,19 & $m$ \\
\hline$<$ median & 70 & 26,81 & 61 & 23,38 & 130 & 49,8 & \\
\hline Total & 189 & 72,4 & 72 & 27,58 & 261 & 100 & \\
\hline
\end{tabular}

*Mc Nemar Test

Knowledge of cadres under mean was decreasing from $49,8 \%$ before intervention to be 27,58 after intervention . Mc Nemar test results obtained $p$ value $=0.001$, there is significanly difference about the knowledge of cadres before and after the intervention. 


\section{International Journal of Science and Research (IJSR) ISSN (Online): 2319-7064}

Index Copernicus Value (2013): 6.14 | Impact Factor (2014): 5.611

Table 3: Attitude of Cadres Before and After Treatment

\begin{tabular}{|c|c|c|c|c|c|c|c|}
\hline \multirow{3}{*}{ PreT est } & \multicolumn{6}{|c|}{ Pre Test } & \multirow{3}{*}{$\begin{array}{c}p- \\
\text { walue }\end{array}$} \\
\hline & \multicolumn{2}{|c|}{$>$ median } & \multicolumn{2}{|c|}{$<$ median } & \multicolumn{2}{|c|}{ Total } & \\
\hline & f & $9 \%$ & f & $\%$ & f & $\%$ & \\
\hline$\geq$ mean & 122 & 46,73 & 30 & 11,49 & 152 & 50,23 & 00 \\
\hline$<$ median & 39 & 14,95 & 70 & 26,81 & 109 & 41,77 & 0,00 \\
\hline Total & 161 & 61,68 & 100 & 38,30 & 261 & 100 & \\
\hline
\end{tabular}

*Mc Nemar Test

Cadres with score attitude more than average has increasing after the intervention, from 152 person $(58,23 \%)$ to 161 person $(61,68 \%)$. Resulth of Mc Nemar test obtained $p$ value $=0.001$. There is a significantly difference attitude of cadres before and after intervention..

\section{Discussion}

Average age of cadres in intervention area was 39 years old with the lowest age of 17 years old and the highest age 68 years old. Average age in the control area is 38 years old with the lowest age of 18 years old and the highest age of 69 years old. cadres in intervention area has an average age higher than cadres in the control area. in the intervention area has 79 cadres $(30.3 \%)$ with aged $<35$ years old and 182 cadres $(69.7 \%)$ with aged $\geq 35$ years old. Same results has found by Ramadani ${ }^{[8]}$. Simanjuntak also found that most of the cadres has aged $\geq 35$ years old. Age 35 years old is an age of psychological maturity, that allows cadres to participate in community in accordance with the period of productive age, because they are not as confined to their homes area with small children who require intensive care ${ }^{[9]}$.

Cadres who work $\geq 5$ years as much as 225 people $(60.8 \%)$, whereas cadres who work $<5$ years as much as 145 people (39.2\%) including newly to be a cadres cadres just a couple months. Average lenght of work cadres in the intervention area was 8.3 years. Average lenght of work cadres in the control was has 9.1 years, longer then lenght of work cadres in the intervention area.

Viewed from length of work cadres in this study, cadres with length of work greater than or equal to 5 years in the intervention area $(56.7 \%)$ less than the cadres in control areas $(70.6 \%)$, that mean, cadres in the control area have length of work as cadres longer then the intervention area. This is convenient with the conditions of health center Lubuk Basung (area of intervention). The intervention area is urban area that has high mobility of the population that causes cadres often drop out. the control area located at rural area, that cadres more likely to survive and not often moved. Results of the analysis significantly differences in length of work as a cadres in the areas of intervention with the control area

The analysis showed significantly difference in length of work as a volunteer in the areas of intervention with the control area. The government of Agam district empowers posyandu cadre as sosialisator, motivator and distributor activities filariasis prevention of medication administration.
Filariasis prevention of medication administration activities have been carried out for 6 consecutive years. For cadres to work $\geq 5$ years is expected to have the skills to implement socialization, motivation and better distribution

From the research there were 233 cadres $(63 \%)$ with higher education category and $137(37 \%)$ with low education category. Cadres in the study areas has higher level of education (high school and above), that mean, cadres has studied 12 years or more. This is consistent with one of the 7 criteria that must be filled by a cadre as stated in the instructions of the Minister of the Interior No. 9 of 1990 on the improvement of quality coaching Posyandu (IHC). The results are consistent with Sari's research which showed that the majority of respondents' education level is high category (more than hight school) [10]. When compared between the areas of intervention and control area, a cadre in control area has education higher then cadres in intervention are. However, statistically both areas there is no difference.

Post intervention data analysis showed an increasing percentage of cadres with a good knowledge of $22.6 \%$. Th same resulth has found at Kumara research that there ar has increasing knoeledge after receiving training. the average score of respondents knowledge increased from 12.9 becomes 17.53 after intervention. There are an increase in knowledge of the respondent after intervention.

Resulth of analizing item questions of knowledge showed the correct answers increasing. Highest correct answers increasing at the questions about the causes of the incident elephantiasis, medication effects include nausea and dizziness, and swelling the scrotum cause filariasis. Knowledge about the causes elephantiasis is a worm that lodged in the blood vessels, glands lymphe and cause swelling, effects include nausea and dizziness. There are information that is meaningful to cadres in providing socialization can encourage people to take preventive medicine.

Refers to the theory of Green, the information submitted by the cadres to the public during the dissemination and distribution of the medication on the disease elephantiasis, is about the mass treatment of disease elephantiasis and provisions taking preventive medication. Socialization held during the distribution of the medication, it will encourage people to take medicine. Elephantiasis disease prevention should be taken once a year for 5 consecutive years.

Statement of attitude in this research is about attitude of cadres against filariasis mass treatment. Statement consists of a positive attitude and negative attitude. Assessment the attitude of cadres in the intervention area showed $66.3 \%$ of cadres have a good attitude, the percentage is higher then control area showed $64.2 \%$. Statisticly resulth shoe that no difference between the attitude of cadres in the intervention area with the control area. After the intervention there is an increasing percentage good attitude at the intervention. Enhancement positive attitude of cadres in the intervention area are higher than controls area.

Although the attitude does not show real action in support of filariasis control activities, but a positive attitude can affect a 


\section{International Journal of Science and Research (IJSR) \\ ISSN (Online): 2319-7064}

Index Copernicus Value (2013): 6.14 | Impact Factor (2014): 5.611

person's behavior because the attitude of a person's have tendency to perform an action.

Research Santoso in east Belitung District showed the positive attitude of respondents can control activities to support the positive behavior ${ }^{[11]}$. According to Green opinion in Notoatmojo, attitude is a predisposing factor for someone to behave ${ }^{[12]}$. Behavior of people taking the medication for prevention of filariasis will be affected by his attitude of society towards the mass treatment. This positive attitude formed when the cadres explain well at socialization.

Cadres were volunteers who are educated and trained in a particular field can grows in the middle of the community and feel obliged to carry out the increase and establish the welfare of the community with a sense of sincere and selfless based on souls to carry out humanitarian tasks. They also called health promoter village ${ }^{[8]}$. The existence of an extension of the health center cadres, because of the limited number of health personnel and as a form of community participation in health development. And the fact is evident from the increase in the percentage of consent after the intervention.

Wijaya found that the health worker with a good attitude to have the possibility to actively 8 times greater than the attitude is not good ${ }^{[6]}$. An increasing percentage of good attitude cadres after the intervention will certainly increase the activity of cadres. Wijaya explain increasing the positive attitude of cadres in the area of intervention will also improve the performance of cadres ${ }^{[6]}$.

Process improvement that occurred in the area of intervention after intervention by the strengthening of social capital will lead to family norms (liability, trust and responsibility) increases, it will increasing the norms of the community directly. It will also improve the social values in society. If the social values in society increases, it will eventually cause medication adherence in society increases seen from the results of the data analysis of mass treatment in 2014 who studied Center for Health Research university of Indonesia at 2015 .

\section{Recommendations}

Type of refreshing cadres to strengthen social capital can be replicated to improve the achievement of health programs that take advantage of the health cadres. Disseminate should held to the relevant staff at the Department of Health and the health center about social capital in the community that can be utilized in other health promotion programs. Socialization can be held through regular meetings that have been there all along.

\section{Acknowledgment}

Researchers would like to thank all those who have helped this research, especially Agam District Health Office and PPKUI.

\section{References}

[1] WHO GPELF, "Monitoring and Epidemiological Assesment of Mass Medication Administration: Lymphatic Filariasis" Geneva, Avenue Appia, 2011

[2] Departemen Kesehatan RI, "Pedoman Pengobatan Massal Penyakit Kaki Gajah (Filariasis)" Buku 4 Jakarta, Ditjen PPM \& PL, 2006

[3] Departemen Kesehatan RI, "Lampiran Keputusan Menteri Kesehatan RI. No.1582/Menkes/SK/XI/2005", Jakarta: Depkes RI, 2005

[4] L Green, "Helath Program Planning: An Educational and Ecological Approach" Mc Graw Hill, New York, 2005

[5] IMK Wijaya, "Pengetahuan, Sikap dan Motivasi terhadap keaktifan Kader dalam Pengendalian Tuberkulosis" Jurnal Kesehatan Masyarakat 8, 2013

[6] Ambarita, "Evaluasi Prototipe Simulasi Sistem Informasi Keperawatan Stroke" Universitas Gadjah Mada, 2007

[7] Zulkifli, "Posyandu dan Kader Kesehatan", 2008

[8] Ramadhani, "Peningkatan Peran Serta Masyarakat Dalam Pengobatan Filariasis Limfatik Di Kecamatan Tirto Kabupaten Pekalongan" Media Peneliti dan Pengembangan Kesehatan, XIX, 2009

[9] Simanjuntak, "Karakteristik Sosial Demografi dan Faktor Pendorong Peningkatan Kinerja Kader Posyandu". JWEM (Jurnal Wira Ekonomi Mikroskil), 2, 2012

[10] D.G. Sari, "Hubungan Peran Serta Kader Dengan Pelaksanaan Posyanu Balita”. Jurnal Kebidanan, IV. No 01,2012

[11] Santoso, et al, "Kepatuhan Masyarakat terhadap Pengobatan Massal Filariasis di Kabupaten Belitung Timur" Media Litbang Kesehatan, 2008

[12] S. Notoatmodjo, "Promosi Kesehatan dan Ilmu Perilaku" Jakarta, Rineka Cipta, 2007

\section{Author Profile}

Fauziah Elytha, Student of Public Health Doctoral Program at Andalas University, Padang, Indonesia. She received the medical doctor degree from Andalas University in 1979 and MSc degree in Public Health from University of Indonesia, Jakarta, Indonesia in 1994. She is a Lecturer in Faculty of Public Health, Andalas University, Padang, Indonesia. 